\title{
An Exploration of Classroom-related Sources of Foreign Language Speaking Anxiety of Pakistani University Students
}

\author{
* Dr. Abdus Samad, Assistant Professor / Chairman (Corresponding Author) \\ ** Dr. Mansoor Ali, Assistant Professor \\ *** Dr. Abdul Karim Khan, Assistant Professor
}

\begin{abstract}
Foreign language anxiety is a distinct variable particular to language learning and it has debilitative effects on the learning and production of language. The current study aims to explore the perspectives of Pakistani postgraduate non-major English language students specifically regarding classroomrelated factors that may contribute to their speaking anxiety (SA). A questionnaire was administered to 170 students and aiming to find a more comprehensive explanation of their SA, 20 students were interviewed. Quantitative data were analyzed through SPSS while exploratory content analysis was followed to analyze the qualitative data. Findings highlight several classroom-related sources of SA namely; a formal classroom environment, oral tests, fear of negative evaluation, large classrooms, fear of being put on the spot, short time granted to formulate answers, and unfamiliarity among classmates. The last four sources of SA have not been mentioned earlier in the field of SA. Implications and recommendations are offered for language teachers and material designers. Finally, recommendations for future studies are given.
\end{abstract}

Keywords: Anxiety; Classroom-related Factors; Fear of Negative Evaluation; Foreign Language Introduction Speaking Anxiety; Pakistan

Malik, Qin, khan, and Ahmed (2020) highlight that English is regarded as an important language in Pakistan; thus there exists a strong instrumental motivation to learn this language. Likewise, Ahmad and Rao (2013) believe that one of the major objectives of Pakistani students and parents in terms of English learning is to develop speaking skills. Despite strong instrumental motivation, many Pakistani researchers (Shahbaz, 2012) lament that the level of spoken proficiency of many Pakistani students is poor. Similarly, Hafeez (2004) stated that many Pakistani students are unable to speak English in various situations. Also, the author concluded that many students state that they feel uncomfortable and uneasy when involved in oral activities in the classroom.

Arnold and Brown (1999:8), state that a student's "anxiety is quite possibly the affective factor that most pervasively obstructs the learning process". Similarly, Liu and Huang (2011) and Milan (2019) believe that anxiety is a major affective factor that predicts students' language performance. Moreover, several studies (Horwitz, 2000; Sadighi \& Dastpak, 2017; Toubot \& Seng, 2018) conclude that at least one-half of all language students may feel SA. Zheng (2008) believes that an oral activity could sometimes be a terrible experience for some learners due to anxiety. Hence, this study aims to explore anxiety as a possible variable affecting Pakistani language learners' speaking performance.

\section{Rationale for the Study}

Firstly, numerous studies (for instance, Milan, 2019; Aydin, 2016) have identified various types of contributors to anxiety, however, a careful analysis of the literature reveals that most of such studies were limited in terms of research sites and sample. Likewise, the focus of these studies was quite general. In other words, these did not specifically investigate classroom-related sources of anxiety but rather discussed sources that may exist outside of the classroom. Eventually, these studies could not provide a comprehensive and deeper understanding of classroom-related sources of anxiety. Many researchers (Horwitz, 2013; Gregersen, \& MacIntyre, 2014) believe that the specificity of language

* Department of English, Kohat University of Science \& Technology, Kohat Email: samadgmm@yahoo.com

** Department of English, Kohat University of Science \& Technology, Kohat Email: sorrorali@ yahoo.com

*** Department of English, UST Bannu. Email: akarim.khan@yahoo.com 
classrooms makes FLA specific to language learning situations. Therefore, it seems imperative to specifically investigate classroom-related sources of speaking anxiety (SA).

Secondly, the field of English language teaching lacks research in Pakistan (Islam, 2013; Shahbaz, 2012). In the same line, research is very sparse in the field of anxiety in Pakistan, and in turn, it is a new and under-research area. Moreover, these studies explored general anxiety and did not focus on SA. This study attempts to fill this research gap in Pakistan. Thirdly, studies such as Alghothani (2010) and Toth (2010) state that the majority of anxiety studies were quantitative therefore, these could not examine anxiety thoroughly. In turn, various studies (Dewaele \& Thirtle, 2009; Piniel, \& Csizérc, 2015) suggest that a combination of both qualitative and qualitative approaches could provide valid and better data about SA. Thus, this study utilized both standpoints to find a more comprehensive and deeper understanding of the complex variable of SA.

\section{Research Question}

- What classroom-related sources do learners believe contribute to speaking anxiety in Pakistani University EFL classrooms?

\section{Potential Significance of the Study}

Keeping in view the shortage of research in the arena of SA in Pakistan, the present study could provide useful recommendations for language instructors, students, and also for educational/language material designers in Pakistan as well as in other countries. Also, it may reveal new avenues for future studies.

\section{Literature Review}

\section{Approaches towards Anxiety}

There are three perspectives to the study of anxiety in language learning namely, state, trait, and situation-specific anxiety. MacIntyre (1999) conceptualizes trait anxiety as, "a feature of an individual's personality and therefore is both stable over time and applicable to a wide range of situations" (p. 28). It is noteworthy that language anxiety is restricted to a particular setting. Nonetheless, trait anxiety is not restricted to a specific setting thus it cannot examine language anxiety. MacIntyre (1999:28) reported that state anxiety is temporary and its level and intensity depend upon the given situation. State anxiety is experienced in response to a particular event and it can decrease when that situation is over. However, state anxiety is criticized because it fails to restrict anxiety to a specific source. Studies following these two approaches of anxiety provided contradictory findings of the influence of anxiety on language acquisition (Horwitz, 2010; Naudhani, et al., 2018; Trang, 2012).

Hence, Horwitz, Horwitz, and Cope (1986) concluded that language anxiety is different from its other perspectives and thus it is unique to language learning settings. She defined foreign language anxiety (FLA) as "a distinct complex of self-perceptions, beliefs, feelings, and behaviors related to classroom language learning arising from the uniqueness of the language learning process" (Horwitz et al., 1986:128). This definition suggests that language anxiety is a discrete phenomenon that is affected by specific features of language acquisition and language use in the classroom. This type of anxiety needs subjects to relate anxious feelings to a specific factor. Thus, it provides a better explanation of FLA.

\section{Language Learning Anxiety Research}

Since the 1970s studies have been reporting that anxiety affects language learning and achievement negatively (Horwitz, 2010). However, most of such studies offered confusing and contradictory conclusions (Horwitz, 2010), In other words, some studies (e.g. Chastain, 1975) showed a negative relationship between anxiety and language learning and others showed no connection or positive connection. Such confusing results could not explain that how anxiety interferes with language learning and language production. One of the reasons for such inconclusive results could be the existence of various types of anxiety and the absence of a valid anxiety measure. However, after the agreement that FLA is particular to language learning situations and the construction of a valid anxiety measure (FLCAS), many studies have given uniform findings and have further confirmed that there exists a negative relationship between anxiety and language learning (Horwitz, 2013).

Since the 1980s anxiety has been found as an independent phenomenon affecting language acquisition (Milan, 2019; Von Worde, 2003). It affects language learning at all levels namely, input, processing, and output (MacIntyre \& Gardner, 1994). Likewise, Krashen (2003) explains that anxiety affects the affective filter and obstructs the mind to understand information. Several studies conclude 
that the majority of students experience speaking anxiety (Liu \& Jackson, 2008; Oteir, \& Al-Otaibi, 2019; Wilson, 2006). Horwitz and Young (1991) assert that the majority of anxious students hold oral activities responsible for their anxiety.

\section{Possible Sources of Anxiety}

Sources of SA range from personal (such as self-esteem) to procedural (e.g. teaching methodology). Several sources are listed below:

\section{Communication Apprehension}

It is one of the major contributors to SA (Aydin, 2016; Dewaele \& MacIntyre, 2014; Trang et al., 2013; Piniel, \& Csizérc, 2015). It could be felt because of several reasons, for example, when learners fail to communicate appropriately due to immature speaking skills and when they imagine that they are not capable of speaking in the foreign language (Horwitz, 2013). It implies that if students rate themselves as incompetent; this feeling may increase their anxiety and discourage them from participating.

\section{Fear of Negative Evaluation}

FNE is regarded as the main source of SA (Alghothani, 2010; Aydin, 2016; Ewald, 2007; Horwitz, 2013). Price (1991) concluded that many students did not participate in oral activities because of the fear that their peers would laugh at them and make fun of them. Similarly, Sadighi and Dastpak (2017) found that their subjects experienced anxiety due to the fear that their classmates would laugh at them and their teacher would judge them negatively. This finding concurs with other studies (for instance, Alghothani, 2010; Ferdous, 2012; Huang, 2009; Lucas et al., 2011; Liu \& Jackson, 2008; Sadighi \& Dastpak, 2017;). It could be argued that FNE may particularly affect those students who lack confidence because they could hardly try to participate in the class because of the fear that their classmates would ridicule them.

\section{Competitiveness}

Many studies highlight competitiveness as one of the main sources of SA (Cheng, 2005; Dewaele \& MacIntyre, 2014; Gregersen \& MacIntyre, 2014; Tóth, 2011; Yan \& Horwitz, 2008). It appears that students may feel anxiety if they feel that their language performance is poorer than that of their classmates. On the other hand, Ewald (2007) concluded that competitiveness was not a source of Spanish students' anxiety. It implies that this factor cannot be generalized to all research sites as a contributor to anxiety. This factor may motivate some students to overcome their shortcomings and improve their performance. In turn, it is suggested that there is a need to explore anxiety in various contexts, such as in Pakistan, to have more reliable results

\section{Learner Beliefs}

Learners' irrational beliefs and false hopes about their language performance have been found as sources of anxiety (Dewaele, \& Thirtle, 2009; Naudhani, \& Naudhani, 2018; Toubot, \& Seng, 2018 ;). For instance, Horwitz's (1988) subjects believed that their utterances must be correct, must achieve native-like fluency within two years, and they believed that only gifted and capable students can learn a language. Besides, some learners may believe that cramming grammar rules and vocabulary are essential to learning a language (Wang, 2005).

\section{Teacher-Student Interaction}

Several studies relate SA with student-teacher relations (Arnold, 2007; Sadighi \& Dastpak, 2017; Tóth, 2011; Milan, 2019). The processes of the classroom could be perceived differently by teachers and students (Horwitz, 1989), and any incongruence between students' learning preferences and teachers' instructional styles may evoke SA for some learners (Wang, 2005). It appears that examining learners' and teachers' views about classroom procedures may better explain learners' SA. Various factors such as harsh error correction, unfriendly teachers, correcting students publically, and students' fear that how their mistakes will be viewed by their peers and teachers evoke anxiety for them (Aida, 1994; Samimy, 1994). Moreover, teacher characteristics such as harsh, rude, strict, unsympathetic, unsupportive contribute to students' SA (Palacios (1998).

\section{Classroom Procedures}

A variety of classroom practices and instructional methods, specifically those that put students at the display, appear to influence the levels of students' anxiety. The following anxiety-inducing classroom practices such as unprompted role play, giving a presentation in front of all students, skits, and speaking in front of the whole class have been reported by Young (1990). Likewise, Sadighi and 
Dastpak (2017) found that students' concern about being put on the spot, expectations about oral production, and the pace of the lecture could trigger anxiety for some students.

\section{Language Testing}

Research reports tests as a source of SA (e.g. Al-Sibai, 2005; Aydin, 2016; Chan \& Wu, 2004; Huang \& Hung, 2013; Lucas et al., 2011; Marwan, 2016; Malik, et al., 2020). This happens specifically when exams are new, confusing, evaluative, and include the material that was not taught in the class (Aydin, 2016). It implies that the more evaluative, new, and ambiguous the exams are, the more SA students may experience. Likewise, tests that determine students' success and achievement could increase SA for them.

It could be concluded that some of the above-described contributors to anxiety may have overlapped. For instance, competitiveness may be associated with test anxiety since learners frequently equate their performance with that of their peers. Likewise, some contributors may depend upon a specific research context, for example, competitiveness, and others on students, such as learning and teaching styles.

\section{Research Methods}

This study utilized both quantitative methods (questionnaire) and qualitative tools (semi-structured interview) to address the questions. Mixed-methodology was adopted with the hope to find a deeper view of the complex nature of anxiety. Keeping in view the aims of the study and previous literature, the questionnaire and interview guide were constructed for the study. Piloting of both of the instruments was carried out before data collection.

\section{Research Sites and Sample}

Research sites include five departments of five universities in Pakistan. The sample for the questionnaire comprised 170 postgraduate students. They were learning English as a non-major subject. I recruited around 30 to 40 students from each department. Participants' age ranged between 19 and 24. Moreover, 20 students, four from each university, were interviewed.

\section{Data Collection and Analysis Procedures}

The study began with the administration of the questionnaire followed by interviews. All of the important ethical considerations were taken into account when collecting the data. The quantitative data were analyzed through SPSS to get percentages and frequencies as shown in table 1 the qualitative data were analyzed through exploratory content analysis. Both qualitative and quantitative findings were integrated and are given together in the analysis.

\section{Results}

The data suggested various classroom-related sources of SA that have been described below. The following table 1 gives students' views to the questionnaire.

\section{Table 1 Students' perceptions about classroom-related sources of SA}

\begin{tabular}{|c|c|c|c|c|c|c|}
\hline No & Statement & $\begin{array}{l}\text { Strongly } \\
\text { Agree }\end{array}$ & Agree & Neutral & Disagree & $\begin{array}{l}\text { Strongly } \\
\text { Disagree }\end{array}$ \\
\hline 1 & $\begin{array}{l}\text { I am afraid that my classmates will laugh } \\
\text { at me when I speak English. } \\
\text { I get nervous during oral tests in my }\end{array}$ & $20.5 \%$ & $55.8 \%$ & $4.1 \%$ & $17 \%$ & $2.3 \%$ \\
\hline 2 & English class. & $12.3 \%$ & $44.1 \%$ & $17.6 \%$ & $17 \%$ & $8.8 \%$ \\
\hline 3 & $\begin{array}{l}\text { I start to panic when I have to speak } \\
\text { without preparation in English class. } \\
\text { I start to panic when I don't have }\end{array}$ & $24.1 \%$ & $52.9 \%$ & $4.1 \%$ & $14.7 \%$ & $4.1 \%$ \\
\hline 4 & $\begin{array}{l}\text { sufficient time to formulate my answer } \\
\text { before speaking. }\end{array}$ & $17 \%$ & $37 \%$ & $15.2 \%$ & $22.9 \%$ & $7.6 \%$ \\
\hline 5 & $\begin{array}{l}\text { It frightens me when I don't understand } \\
\text { what the teacher is saying in English. } \\
\text { I feel very self-conscious about speaking }\end{array}$ & $4.1 \%$ & $40.5 \%$ & $23.5 \%$ & $22.3 \%$ & $9.4 \%$ \\
\hline 6 & $\begin{array}{l}\text { English in front of my classmates. } \\
\text { Even if I am well prepared for oral tasks, }\end{array}$ & $25.2 \%$ & $49.4 \%$ & $7 \%$ & $16.4 \%$ & $1.7 \%$ \\
\hline 7 & $\begin{array}{l}\text { I feel anxious about them. } \\
\text { I feel very self-conscious about speaking }\end{array}$ & $8.2 \%$ & $29.4 \%$ & $8.8 \%$ & $42.9 \%$ & $10.5 \%$ \\
\hline 8 & $\begin{array}{l}\text { English in a formal classroom } \\
\text { environment } \\
\text { I feel anxious about speaking English in }\end{array}$ & $30 \%$ & $40 \%$ & $10 \%$ & $18.4 \%$ & $1.6 \%$ \\
\hline 9 & a large class. & $20.5 \%$ & $40 \%$ & $8.8 \%$ & $22.3 \%$ & $8.2 \%$ \\
\hline
\end{tabular}




\begin{tabular}{ll}
\hline \hline $\begin{array}{l}\text { I can feel my heart pounding when I am } \\
\text { going to be put on the spot in English }\end{array}$ \\
\begin{tabular}{l} 
class. \\
\hline
\end{tabular}
\end{tabular}

\section{A Formal Classroom}

The data revealed that language classroom that is "strict", "dry", "formal", "and tense" and "evaluative" can evoke higher levels of SA for some learners. The data further suggested that such an environment can create self-consciousness in students and it can lead to fear of negative evaluation and of making mistakes. Most of the students reported that in this negative environment, they try to be correct but they cannot perform well and in turn, they become self-conscious. Students believed that a strict and formal classroom is a significant contributor to their SA. This result lends its further support from item 8 in table 1 above, as $70 \%$ of the students agreed with this item.

\section{Large Classrooms}

Surprisingly, the findings showed that large classrooms can also cause SA. Item 9 in table 1 supports this finding where $60.5 \%$ of students supported this statement. Students' interviews revealed that large classrooms trigger anxiety, for example, one student stated that it could be easier and less anxietyprovoking for him if he is allowed to speak when there are not too many students in the class. Some students stated that due to large classrooms teachers do not have enough time to pay due attention to each student. Some students believed that they experience anxiety when they feel that teacher is not paying attention to them.

\section{Unfamiliarity among Classmates}

The data revealed that lack of familiarity and openness among classmates may arouse fears such as fear of making mistakes, FNE, and fear of being laughed at. On the other hand, the students reported that they would feel more comfortable, encouraged, and confident if they are well familiar with their peers and they have friendly relations with each other.

\section{Fear of Negative Evaluation}

The findings revealed that if students could not perform well in oral tasks, or made mistakes when speaking, their classmates and the teacher would judge them negatively and rate them as "incapable students". Additionally, teacher's poor view of them could influence their grades. This result concurs with the findings of Kim (2009) and Tóth (2010).

Almost all interviewees stated that oral activities induced anxiety for them when they were required to speak in front of the peers who were evaluating them, could laugh at their poor performance, and may make a negative perception about them. Besides, they believed that they are fine until they communicate and reveal their weaknesses, and show themselves as inefficient learners. This result agrees with item 6 above as $74.6 \%$ of students agreed with this statement.

Interestingly, FNE may motivate some learners, for instance, Javed was motivated by this factor and he took it as a challenge and he increased his efforts to improve his performance and in turn, his image in the class. Hence, it implies that students' views and criticism about each other could be taken as a positive factor if they regard themselves as helpers and not evaluators.

\section{Fear of being laughed at}

Almost all of the interviewees stated that they prefer to sit silent, avoid answering, avoid asking questions, and avoid participating actively as they have a fear of being laughed at. In other words, they believed that other students would laugh at them and make fun of them if they make mistakes, fail to answer correctly or their question is silly. This situation is clear from Tahir's comment: "If my answer or question is wrong, my peers laugh at me". This agrees with item 1 in Table 1 where $76.3 \%$ of students agreed with this item. Similarly, Hashim did not participate in the class due to the fear of being made fun of.

\section{Fear of being put on the Spot}

Fear of being put on the spot was also found anxiety-provoking by the majority of the students. The interviews revealed that students feel less confident and more self-conscious when they are asked to speak on the spot. Some of the interviewees offered the reasons as well, for example, Javed stated that in such situations he makes many mistakes and his mind goes blank. This finding lends its support from item 10 in table 1 as $51.1 \%$ of students agreed with this statement.

\section{Lack of Preparation}

Lack of preparation was found as a contributor to anxiety. Item 4 in table 1 supports this finding as $77 \%$ of students supported this statement. On the other hand, $53.4 \%$ of students rejected item 8 in Table 1. It means that although learners may experience lower levels of anxiety when prepared, oral 
activities may still provoke anxiety. The interview data indicated that students may feel flustered, lose confidence, and may not perform activities well if asked to speak unprepared. It was found that lack of preparation causes more mistakes and consequently, students may experience other fears such as fear of being laughed at.

\section{Lack of Practice}

Many interviewees believed that lack of practice causes SA. They believed that they can't speak comfortably and confidently because they are not given opportunities to practice speaking English. They blamed their teachers that their main aim is to deliver their lectures and they do not give students activities or chances to rehearse speaking. In turn, they make mistakes in terms of vocabulary, grammar, and pronunciation when speaking. Eventually, they experience anxiety.

\section{Short Time Granted to Formulate Answers}

The findings suggested that giving students a little time to answer the instructor's question or to perform oral activities in front of the students may generate anxiety for some learners. Item 4 in Table 1 , also supports this finding, as $54 \%$ of students agreed with this statement. Learners were not efficient enough to answer quickly and appropriately; hence, they required time. However, the teacher wanted them to answer quickly, consequently, they got confused and committed mistakes which increased their anxiety. Similarly, they might be trying to formulate an answer on one hand, and on the other, they may have a fear that they have a short time or the teacher may ask this question to another student. In this line, some studies have concluded that short time negatively influences students' oral production (e.g., Aydin, 2016; Malik et al; 2020). The interviews indicated that students needed time to work on grammar, vocabulary, and brilliant ideas before answering. However, they were asked to speak quickly but when they spoke quickly they made mistakes and in turn, experienced anxiety.

\section{Unfamiliar Activities and Unfamiliar and Difficult Topics}

The majority of interviewees stated that they become uneasy, flustered, and uninterested when their instructor assigns them dry, uninteresting, and complicated topics to speak on. They believed that they don't have the required knowledge about difficult topics and thus they experience anxiety. Moreover, Tahir's following comment suggests that unfamiliar classroom activities could also provoke SA: "some teachers give us unfamiliar activities. I start trembling because I even don't know what the activities are about". Moreover, the quantitative data revealed that students became anxious when they failed to understand their teacher when he/she talked about unfamiliar stuff. This finding agrees with item 5 in Table 1 as $44.6 \%$ of students agreed with this item.

\section{Oral Tests}

The data revealed that oral activities for instance discussions, presentations, and role plays could provoke anxiety for some learners particularly when their oral performance is rated. This result agrees with item 2 in table 1 as $56.4 \%$ of students agreed with this item. Students believed that they are not at rest when they know that their spoken performance will be evaluated. Another finding suggested that including unfamiliar materials in tests could escalate students' anxiety levels about tests. Some students believed that their minds went blank during oral tests.

\section{Discussion}

FNE and fear of being laughed at have been frequently reported as contributors to SA (see, for example, Huang, 2009; Liu \& Jackson, 2008; Oteir, \& Al-Otaibi, 2019). It is suggested that if learners are very much concerned about their positive image in the class, they might not focus on the assigned learning task and could just concentrate on their anxiety. Eventually, such learners may avoid speaking practices permanently or may involve themselves nominally in classroom activities in which learners imagine that they could be judged negatively. I think if such students regularly avoid oral activities due to fear of negative evaluation, they may improve less which could, in turn, increase their disappointment. Pakistani culture does not appreciate one to be perceived as less capable than his/her fellows and consequently be evaluated unfavorably (Parveen, 2007). The writer further notes that those who are considered competent are taken as important and respectable. In turn, the learners may imagine that if they can't perform well, they may lose their faces. On the other hand, for some learners, their classmates' views may not induce SA but rather give them a push. I suggest that a language classroom is a setting where students' deficiencies are exposed and FNE is developed; thus, instructors may give learners a friendly and psychologically secure classroom atmosphere that may help to alleviate FNE. 
Moreover, language learners could feel anxiety if they are not given adequate time to answer. They were not competent enough to reply quickly and appropriately; hence, they required time. However, the teachers asked them to respond quickly, consequently, they became confused and could not do well in oral tasks which in turn increased their anxiety. Likewise, on one hand, they might be trying to collect ideas for the answer and on the other, they may have a fear that they may not have enough time and the teacher may switch to another student. Thus, they may feel embarrassed and they could think that they will be evaluated negatively. Toubot, and Seng (2018) report that inadequate time influences the production of speech negatively.

Lack of preparation can also cause SA. This finding agrees with Liu (2007) whose subjects stated that their minds went blank when asked to speak without preparation in the class. Aydin (2016) believes that some students may not have linguistic competence, therefore, they may need time to think about linguistic elements such as grammar. If students are asked to perform oral tasks unprepared, they may not do well and in turn, they may experience frustration. Consequently, students may lose interest in speaking and avoid participation in classroom activities. Moreover, unpreparedness may lead to other contributors of anxiety, for example, FNE, FMM, and lack of selfesteem. Likewise, if students are not given chances of practicing English speaking they may always be afraid of speaking English due to the fears such as FNE and fear of mistakes. Thus, students may avoid being involved in oral activities.

Oral tests can also cause students' SA. Many other researchers share this result in other research settings (e.g. Huang \& Hung, 2013; Lucas et al., 2011; Liu \& Jackson, 2008; Milan, 2019; Toubot, \& Seng, 2018). Several reasons could be responsible for students' oral test anxiety. Students may have poor speaking skills and Horwitz (2013) believes that lack of speaking competency induces anxiety. Additionally, tests and evaluations are common practices in a language classroom, hence, students may develop a strong fear about tests. Moreover, poor vocabulary, false beliefs, grammar, and unfamiliar topics could also lead to oral test anxiety.

A judgemental classroom environment may also evoke SA and this result agrees with previous studies (Aydin, 2016; Malik, et al., 2020; Toubot, \& Seng, 2018). However, some students may think that a formal classroom is important for good learning. Hence, instructors may be judicious to address learners' learning styles and preferences. One of the reasons for this finding in the Pakistani setting could be that teachers get poor salaries in Pakistan (Shahbaz, 2012). Thus, most of the teachers join teaching when they fail to find well-paid jobs. In turn, they may not like this profession and may not be economically contented. Therefore, they may be socially and emotionally frustrated, and such teachers mostly create a strict classroom atmosphere (Jennings \& Greenberg, 2009). Moreover, large classes could also induce SA. Many Pakistani writers state that classes are mostly big in Pakistan and large classes influence the language learning process. (Rahman, 2007; Shamim \& Tribble, 2005). Likewise, large classes could affect teachers' performance and attitude as they may not be able to teach effectively.

\section{Implications}

Perhaps the major suggestion is that teachers may be familiar with SA, they should accept its existence in a language classroom and may pay due consideration to students' SA. Secondly, in terms of FNE, teachers should incorporate activities that don't put students at the display. In this reference, teachers may allow students to perform in pairs or groups. In this way, students will not think that they are alone. Eventually, they may feel more confident and encouraged to participate more in oral tasks. Thirdly, teachers should give enough time to students to practice oral tasks and prepare them in advance. Similarly, the teacher could give adequate time to students to respond comfortably. Fourthly, it is recommended that instructors should build students' confidence for instance by assigning them easy oral tasks and by giving them encouraging feedback. In turn, students may feel less FNE.

Additionally, teachers may alleviate their students' SA through effective consultations and communication. Likewise, seminars and workshops may also prove helpful in making students aware of anxiety and how it can be countered. Likewise, teachers may provide students with an open, frank, friendly, and social classroom atmosphere. In such an environment, students may have less FNE and fear of making mistakes and may feel encouraged to take risks and increase participation in the classroom.

Similarly, teachers should teach speaking skills using motivating, simple, and familiar classroom activities to increase their interest in the learning process. Likewise, teachers should assign simple, 
more relevant, and interesting topics for oral activities to students. Students who experience oral test anxiety could practice oral tests in advance, their exams may be conducted alone or in groups and they should be given enough time for tests. Moreover, they should not be given marks just for a correct answer but also for conveying the message appropriately too. Finally, new practices such as mentors, language support units, and student counseling centers may be introduced in the higher education institutions of Pakistan.

\section{Conclusion}

This mixed-method study attempted to explore the classroom-related factors that may contribute to students' SA. The data revealed various sources such as oral tests, unpreparedness, FNE, and the short time given to frame answers. It was found that students experience anxiety when they are asked to perform unprepared. This apprehension may be aggravated by their feeling of low proficiency in speaking and that their language deficiencies will be exposed in front of others. This study suggests that SA is not simply an add-on factor in language acquisition but rather it seems a pervasive phenomenon in language classrooms. Therefore, it demands focused attention and a strong role from language instructors and policy-makers to counter it. Moreover, foreign language acquisition is a difficult endeavor and it is a personal and ego-involving process. As teachers, we must protect students' interest to learn it and make it a pleasant and successful experience for them. By decreasing anxiety, we may start to move in that direction. Hopefully, this study has raised teachers' and educators' awareness about the construct of SA. It could be useful to repeat this work with a larger sample in other areas of Pakistan. Moreover, investigating the function of anxiety concerning other skills i.e. listening, writing and reading could increase our understanding of anxiety.

\section{References}

Ahmad, S., \& Rao, C. (2013). Applying communicative approach in teaching English as a foreign language: A case study of Pakistan. Porta Linguarum, 20 (1), 187-203.

Aida, Y. (1994). Examination of Horwitz, Horwitz and Cope's construct of foreign language anxiety: The case of students of Japanese. The Modern Language Journal, 78(2), 155-168.

Alghothani, D. (2010). Foreign language anxiety in an intermediate Arabic reading course: A comparison of heritage and foreign language. Unpublished doctoral dissertation. Ohio State University.

Al-Sibai, D. M. (2005). L2 anxiety of Saudi female university students enrolled in speaking courses. Retrieved 25 July 2009, from http://docs.ksu.edu.sa/PDF/Articles47/Article470521.pdf

Arnold, N. (2007). Reducing foreign language apprehension with computer-mediated communication: A preliminary study. The system, 35(4), 469-486.

Arnold, J., \& Brown, H. D. (1999). A map of the terrain. In J. Arnold (Ed.), Affect in Language Learning (pp.1-24). Cambridge: Cambridge University Press.

Aydin, S. (2016). Qualitative research on foreign language teaching anxiety. The Qualitative Report, 21(4), 629-642. Retrieved from http://nsuworks.nova.edu/tqr/vol21/iss $4 / 2$

Chan, D. Y., \& Wu, G. C. (2004). A study of foreign language anxiety of EFL elementary school students in Taipei County. Journal of National Taipei

Chastain, K. (1975). Affective and ability factors in second language acquisition. Language Learning, $25,153-161$.

Cheng, C. J. (2005). The relationship of foreign language anxiety of oral performance achievement, teacher characteristics, and in-class activities. Unpublished MA dissertation, Ming Chun University, Taipei City.

Clément, R., Gardner, R. C., \& Smythe, P. C. (1977). Motivational variables in second language acquisition: A study of Francophones learning English. Canadian Journal of Behavioral Science, 9(2), 123-133.

Dewaele, J. M., \& MacIntyre, P. D. (2014). The two faces of Janus? Anxiety and enjoyment in the foreign language classroom. Studies in Second Language Learning and Teaching, 4(2), 237274.

Dewaele, J. M., \& Thirtle, H. (2009). Why do some young learners drop foreign languages? A focus on learner-internal variables. International Journal of Bilingual Education and Bilingualism, 12(6), 635-649.

Ewald, J. D. (2007). Foreign language learning anxiety in upper-level classes: Involving students as researchers. Foreign Language Annals, 40, 122-142. 
Ferdous, F. (2012). A case study of first-year-non-English undergraduate students' English learning anxiety in Bangladesh. Journal of Education and Practice, 3(9), 1-12.

Gregersen, T. S., \& MacIntyre, P. D. (2014). Capitalizing on Language Learners' Individuality: From Premise to Practice. Bristol, England: Multilingual Matters, Pp. xxvii-259.

Hafeez, A. (2004). The need of introducing communicative syllabuses for teaching English in Pakistan. Journal of Research (Faculty of Languages \& Islamic Studies), 6(2), 27-32.

Horwitz, E. K. (1988). The beliefs about language learning of beginning university foreign language students. The Modern Language Journal, 72(3), 283-294.

Horwitz, E. K. (1989). Recent research on second language learners: Beliefs and anxiety. Texas Papers in Foreign Language Education, Special Edition, 2, 283-294.

Horwitz, E. K. (2000). It ain't over until it's over: On foreign language anxiety, first language deficits, and the confounding of variables. The Modern Language Journal, 84, 256-259.

Horwitz, E. K. (2001). Language anxiety and achievement. Annual Review of Applied Linguistics, 21, 112-126.

Horwitz, E. K. (2010). Foreign and second language anxiety. Language Teaching, 43, 154-167.

Horwitz, E. K. (2013). Becoming a Language Teacher: A practical guide to second language learning and teaching $\left(2^{\text {nd }}\right.$ ed). Pearson.

Horwitz, E. K., Horwitz, M., \& Cope, J. (1986). Foreign language classroom anxiety. The Modern Language Journal, 70(2), 125-132.

Horwitz, E. K., \& Young, D. (1991). Language Anxiety: From theory and research to classroom implications. Englewood Cliffs, N.J: Prentice-Hall.

Huang, H. T., \& Hung, S. T. (2013). Comparing the effects of test anxiety on independent and integrated speaking test performance. TESOL Quarterly, 47(2), 244-269. Teachers College, $17(2), 287-320$.

Huang, Y. M. (2009). Listening to their voices: An in-depth study of language anxiety and cultural adjustment among Taiwanese graduate students in the United States. Unpublished doctoral dissertation, Indiana University of Pennsylvania.

Islam, M. (2013). L2 motivational self-system and relational factors affecting the L2 motivation of Pakistani students in the public universities of central Punjab, Pakistan. Unpublished doctoral dissertation, University of Leeds, UK.

Kim, S. Y. (2009). Questioning the stability of foreign language classroom anxiety and motivation across different classroom contexts. Foreign Language Annals, 42(1), 138-157.

Kleinmann, H. (1977). Avoidance behavior in adult second language acquisition. Language Learning, 27, 93-107.

Krashen, S. D. (1982). Principles and Practice in Second Language Acquisition. New York: Pergamon Press.

Liu, M. (2007). Anxiety in oral English classrooms: A case study in China. Indonesian Journal of English Language Teaching, 3(1), 119-137.

Liu, M., \& Huang, W. (2011). An exploration of foreign language anxiety and English motivation. Education Research International, 1-8.

Liu, M., \& Jackson, J. (2008). An exploration of Chinese EFL learners' unwillingness to communicate and foreign language anxiety. The Modern Language Journal, 92(1), 71-86.

Lucas, R., Miraflores, E., \& Go, D. (2011). English language learning anxiety among foreign language learners in the Philippines. Philippine ESL Journal, 7, 94-119.

MacIntyre, P. D. (1999). Language anxiety: A review of the research for language teachers. In D. J. Young (Ed.), Affect in Foreign Language and Second Language Learning: A practical guide to creating a low-anxiety classroom atmosphere (pp. 24-45). Boston: McGraw-Hill.

MacIntyre, P. D., \& Gardner, R. C. (1991). Investigating language class anxiety using the focused essay technique. The Modern Language Journal, 75, 296-304.

MacIntyre, P. D., \& Gardner, R. C. (1994). The subtle effects of language anxiety on cognitive processing in the second language. Language Learning, 44, 283-305.

Malik, S., Qin, H., Khan, S. M., \& Ahmed, K. (2020). Quantitative Analysis of the Foreign Language Anxiety: Chinese and Pakistani Postgraduates in Focus. Arab World English Journal, 11 (1) 315-330. 
Marwan, A. (2016). Investigating students' foreign language anxiety. Malaysian Journal of ELT Research, 3(1), 19.

Mersi, F. (2012). The relationship between gender and Iranian EFL learners' foreign language classroom anxiety (FLCA). International Journal of Academic Research in Business and Social Sciences, 2(6), 147-156.

Milan, M. (2019). English speaking anxiety: sources, coping mechanisms, and teacher management. International Journal of Teaching, Education, and Learning, 3-2.

Naudhani, M. Wu. Z. \& Naudhani, S (2018). Exploring the factors of foreign language anxiety among Chinese undergraduate English majors and Non-English majors. International Journal of English Linguistics, 8-5

Oteir, I. N., \& Al-Otaibi, A. N. (2019). Foreign Language Anxiety: A Systematic Review. Arab World English Journal, 10 (3) 309-317.

Oxford, R. L. (1999). Anxiety and the language learner: New insights. In J. Arnold (Ed.), Affect in Language Learning (pp.58-67). Cambridge: Cambridge University Press.

Palacios, L. M. (1998). Foreign language anxiety and classroom environment: A study of Spanish university students. Unpublished doctoral dissertation, The University of Texas, Austin.

Parveen, A. (2007). Effect of home environment on personality and academic achievement of students of grade 12 in Rawalpindi division. Unpublished doctoral dissertation, National University of Modern Languages, Islamabad, Pakistan.

Piniel, K., \& Csizér, K. (2015). Changes in motivation, anxiety, and self-efficacy during an academic writing seminar. In Z. Dörnyei, P. MacIntyre, \& A. Henry (Eds.), Motivational dynamics in language learning (pp.164-194). Bristol, UK: Multilingual Matters.

Price, M. L. (1991). The subjective experience of foreign language anxiety: Interviews with highly anxious students. In E. K. Horwitz \& D. J. Young (Eds.), Language Anxiety: From theory and research to classroom implications (pp. 101-108). Englewood Cliffs, N.J: Prentice-Hall.

Rahman, T. (2009). Language ideology, identity, and the commodification of language in the call centers of Pakistan.

Sadighi, F., \& Dastpak, M. (2017). The sources of foreign language speaking anxiety of Iranian English language learners. International Journal of Education and Literacy Studies, 5(4), 111 115 .

Samimy, K. K. (1994). Teaching Japanese: Consideration of learners' affective variables. Theory and Practice, 33, 29-33.

Scovel, T. (1978). The effect of effect on foreign language learning: A review of the anxiety research. Language Learning, 28(1), 129-142.

Shahbaz, M. (2012). A study of motivational factors for English language learning in Pakistan: A socio-contextual perspective. Unpublished doctoral dissertation, Northeast Normal University Changchun Jilin P.R. China.

Shamim, F., \& Tribble, C. (2005). Current provisions for English language teaching in higher education in Pakistan. Report submitted to National Committee on English Higher Education Commission, Islamabad.

Tobias, S. (1986). Anxiety and cognitive processing of instruction. In R. Schwarzer (Ed.), Self-related Cognition in Anxiety and Motivation (pp. 35-54). Hillsdale, NJ: Erlbaum.

Tóth, Zs. (2010). Foreign Language Anxiety and the Advanced Language Learner: A study of Hungarian students of English as a foreign language. England: Cambridge Scholars Publishing.

Tóth, Zs. (2011). Foreign language anxiety and advanced EFL learners: An interview study. WoPaLP, 5, 39-57.

Toubot, A. M., \& Seng, G. H. (2018). Examining Levels and Factors of Speaking Anxiety among EFL Libyan English Undergraduate Students. International Journal of Applied Linguistics and English Literature, 7(5), 47-56.

Trang, T. T. T. (2012). A review of Horwitz, Horwitz, and Cope's theory of foreign language anxiety and the challenges to the theory. English Language Teaching, 5(1), 69-75.

Trang, T. T. T., Baldauf, R. B. J., \& Moni, K. (2013). Foreign language anxiety: Understanding its status and insiders' awareness and attitudes. TESOL Quarterly, 47(2), 216-243. 
Tsiplakides, I., \& Keramida, A. (2009). Helping students overcome foreign language speaking anxiety in the English classroom: Theoretical issues and practical recommendations. International Education Studies, 2(4), 39-44.

Von Worde, R. A. (2003). Students' perspectives on foreign language anxiety. Inquiry, 8(1).

Wang, N. (2005). Beliefs about language learning and foreign language anxiety: A study of university students learning English as a foreign language in Mainland China. Unpublished MA dissertation, University of Victoria, Saanich, British Colombia.

Wilson, T. J. S. (2006). Anxiety in learning English as a foreign language: Its association with student variables, with overall proficiency, and with performance on an oral test. Unpublished doctoral dissertation, University of Granada.

Young, D. J. (1990). An investigation of students' perspectives on anxiety and speaking. Foreign Language Annals, 23(6), 539-553.

Zheng, Y. (2008). Anxiety and second/foreign language learning revisited. Canadian Journal for New Scholars in Education, 1(1), 1-12. 